\title{
Normal Values and Associated Factors in High- resolution Anorectal Manometry in Healthy Vietnamese Adults
}

\section{Valores normais e fatores associados na manometria anorretal de alta resolução em adultos vietnamitas saudáveis}

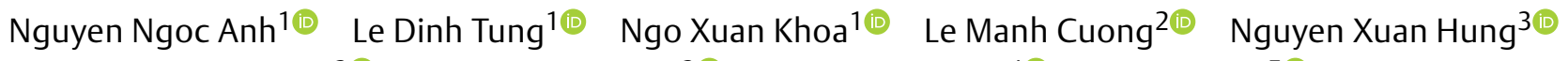
Nguyen Thi Thu Hang ${ }^{3(-)}$ Pham Phuc Khanh ${ }^{3(-)}$ Nguyen Van Huy ${ }^{4}$ Vu Duy Kien ${ }^{5}$ ()

1 Hanoi Medical University, Hanoi, Vietnam

${ }^{2}$ National Hospital of Traditional Medicine, Hanoi, Vietnam

3 Viet Duc Hospital, Hanoi, Vietnam

${ }^{4}$ Graduate School of Public Health, St. Luke's International University,

Tokyo, Japan

5 OnCare Medical Technology Company Limited, Hanoi, Vietnam

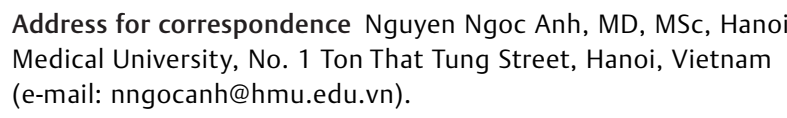
Medical University, No. 1 Ton That Tung Street, Hanoi, Vietnam (e-mail: nngocanh@hmu.edu.vn).

J Coloproctol 2021;41(1):70-78.

\begin{abstract}
\section{Keywords}

- high-resolution anorectal manometry

- anorectal manometry

- normal values

- healthy people

- Vietnam
\end{abstract}

Introduction The present study aims to identify normal high-resolution anorectal manometry (HRAM) values and related factors in healthy Vietnamese adults.

Methods The present cross-sectional study was conducted at the Viet Duc hospital, Hanoi, Vietnam, during April and May 2019. Healthy volunteers were recruited to participate in the study. Anorectal measurement values from the digestive tract, including pressure, were recorded.

Results A total of 76 healthy volunteers were recruited. The mean functional anal canal length was $4.2 \pm 0.5 \mathrm{~cm}$, while the mean anal high-pressure zone length was $3.4 \pm 0.5 \mathrm{~cm}$. The mean defecation index was $1.4 \pm 0.8$, with values ranging from 0.3 to 5.0. The mean threshold volume to elicit the rectoanal inhibitory reflex (RAIR) was $18.1 \mathrm{~mL}$. The mean rectal sensation values were $32.4 \mathrm{~mL}, 81.6 \mathrm{~mL}$, and $159 \mathrm{~mL}$ for first sensation, desire to defecate, and urge to defecate, respectively. Dyssynergic patterns occurred in $\sim 50 \%$ of the study participants and included mainly types I $(27.6 \%)$ and III (14.6\%). There were significant differences between male and female patients in terms of maximum anal squeeze pressure, maximum anal cough pressure, maximum anal received

October 1, 2020

accepted

January 18, 2021
DOI https://doi.org/

$10.1055 / \mathrm{s}-0041-1726078$ ISSN 2237-9363. (c) 2021. Sociedade Brasileira de Coloproctologia. All rights reserved.

This is an open access article published by Thieme under the terms of the Creative Commons Attribution-NonDerivative-NonCommercial-License, permitting copying and reproduction so long as the original work is given appropriate credit. Contents may not be used for commercial purposes, or adapted, remixed, transformed or built upon. (https://creativecommons.org/ licenses/by-nc-nd/4.0/)

Thieme Revinter Publicações Ltda., Rua do Matoso 170, Rio de Janeiro, RJ, CEP 20270-135, Brazil 


\section{Resumo}

\section{Palavras-chave}

- manometria anorretal de alta resolução

- manometria anorretal

- valores normais

- pessoas saudáveis

- Vietnã strain pressure, maximum rectal cough pressure, and maximum rectal strain pressure (all $p<0.01$ ).

Conclusions The present study establishes normal HRAM values in healthy Vietnamese adults, particularly regarding normal values of anorectal pressure and rectal sensation. Further studies that include larger sample sizes should be conducted to further confirm the constants and their relationships.

Introdução O presente estudo tem como objetivo identificar valores normais de manometria anorretal de alta resolução e fatores relacionados em adultos vietnamitas saudáveis.

Métodos O presente estudo transversal foi conduzido no hospital Viet Duc, Hanói, Vietnã, durante abril e maio de 2019. Voluntários saudáveis foram recrutados para participar do estudo. Valores de medição anorretal, incluindo pressão do trato digestivo, foram registrados.

Resultados Um total de 76 voluntários saudáveis foram recrutados. O comprimento funcional médio do canal anal foi de $4,2 \pm 0,5 \mathrm{~cm}$, enquanto o comprimento médio da zona anal de alta pressão foi de $3,4 \pm 0,5 \mathrm{~cm}$. O índice médio de defecação foi de $1,4 \pm 0,8$, com valores variando de 0,3 a 5,0. O volume limite médio para eliciar o reflexo inibitório retoanal (RAIR, sigla em inglês) foi de $18,1 \mathrm{~mL}$. Os valores médios da sensação retal foram $32,4 \mathrm{~mL}, 81,6 \mathrm{~mL}$ e $159 \mathrm{~mL}$ para a primeira sensação, o desejo de defecar e a urgência de defecar, respectivamente. Os padrões dissinérgicos ocorreram em aproximadamente $50 \%$ dos participantes do estudo e incluíram principalmente os tipos I (27,6\%) e III (14,6\%). Houve diferenças significativas entre homens e mulheres na pressão de compressão anal máxima, pressão de tosse anal máxima, pressão de distensão anal máxima, pressão de tosse retal máxima e pressão de distensão retal máxima (todos $p<0,01$ ).

Conclusões $\mathrm{O}$ presente estudo estabelece valores normais de HRAM em adultos vietnamitas saudáveis, particularmente no que diz respeito aos valores normais de pressão anorretal e sensação retal. Mais estudos que incluam tamanhos de amostra maiores devem ser realizados a fim de confirmar melhor as constantes e suas relações.

\section{Introduction}

Anorectal manometry (ARM) is a primary method for evaluating the anorectal function. ${ }^{1,2}$ While conventional ARM has been used to effectively diagnose and manage anorectal disorders, ${ }^{3-5}$ this technique has limitations that affect the measurement and interpretation of results. ${ }^{6,7}$ In response to these limitations, high-resolution anorectal manometry (HRAM) has been developed over the past 10 years and has been shown to provide advantages in comparison with conventional ARM. ${ }^{2}$ Among these, the most advantageous aspects of HRAM include improvements to the sensor systems and to the computer software used to record and replicate ARM values over time and anorectal locations. The HRAM uses the technique of stationary examination to provide detailed topographic and colorimetric mapping of the anorectal area. ${ }^{2}$ To standardize the HRAM technique, it is necessary to identify normal values that can be used as a baseline for comparison with specific disease cases. Therefore, knowledge of normal HRAM values enhances our understanding of anorectal disorder-related diseases.
Studies regarding normal HRAM values in healthy people have been conducted in several countries..$^{8-11}$ In Vietnam, a single study using HRAM has been conducted, which reported values in patients with hemorrhoids before and after doppler-guided transanal hemorrhoidal dearterialization. ${ }^{12}$ Although the HRAM technique has become commonly used in Vietnam, normal HRAM values have not been available until now. Therefore, the aim of the present study is to identify normal HRAM values and related factors in healthy Vietnamese adults.

\section{Methods}

The present cross-sectional study was conducted at the Viet Duc hospital, Hanoi, Vietnam, during April and May, 2019. The present study received ethical approval from the ethics committee of the Hanoi Medical University, Hanoi, Vietnam (ref. 21NCS17/HDDDDHYHN; dated 08/02/2018). Healthy volunteers were recruited to participate in the study. We randomly selected participants based on the list of people who signed up for health checks in a commune health center. 
Healthy people were defined as those who were free from any anorectal diseases and of any other chronic diseases. The participants of the study received an explanation about the aims and objectives of the study, possible adverse effects of anorectal HRAM, and the right to withdraw from the study at any time without consequences. All participants provided written consent before participating in the study.

We calculated the sample size using the formula for estimating a population mean proposed by the World Health Organization (WHO) using a significance level of $0.05 .^{13}$ We assumed a maximum resting pressure of $69.1 \mathrm{~mm} \mathrm{Hg}$ according to values reported by Li et al. ${ }^{9}$ We assumed a population standard deviation (SD) of the maximum resting pressure of $15 \mathrm{~mm} \mathrm{Hg}$ and a relative precision of $5 \%$. After controlling for an estimated $5 \%$ nonresponse rate, we calculated a minimum sample size of 76 patients.

The inclusion criteria for participants included age between 18 and 75 years old, normal defecation for the 3 months prior to enrollment, and normal physical abdominal and digital anorectal examinations. The exclusion criteria included constipation (defined as having fewer than three bowel movements a week), fecal incontinence, obstructed defecation, hematochezia, hemorrhoid, rectal mucus discharge, and any history of anorectal diseases. We excluded pregnant women, people with cardiovascular, respiratory, psychiatric, neurologic, endocrine, hepatic, or renal diseases. Digital rectal examination was performed in all participants to ensure they were free from any anorectal diseases. We also collected relevant patient data, such as gender, age, height, and weight.

Anorectal manometry was performed using the ISOLAB high-resolution manometry system (Standard Instruments $\mathrm{GmbH}$, Karlsruhe, Germany), which included a 6-mm diameter catheter probe possessing 8 channel sensors. Anorectal measurement values from the digestive tract, including pressure, were recorded. We used the Visible Medical Data (ViMeDat; Standard Instruments $\mathrm{GmbH}$, Karlsruhe, Germany) software to extract values after the measurement. Bowel preparation included a Fleet enema (C.B. Fleet Company, Inc., Lynchburg, VA, USA) or patient defecation, if possible, 2 hours before the measurement. All measurements were taken with the study participants placed in the left-lateral position with knees and hips flexed at an angle of $90^{\circ}$. The catheter probe was lubricated and gently inserted into the rectal ampulla $\sim 6 \mathrm{~cm}$ from the anal verge, while maintaining the most proximal sensor of the catheter probe outside of the anal canal. We assessed anorectal parameters during periods of resting, squeezing, pushing, and coughing. During the resting period, the participant relaxed by lying still and not speaking for $\sim 5$ minutes. During the squeezing period, the participant was instructed to squeeze the anal canal as tightly as possible for $\sim 20$ seconds. During the pushing period, the participant was asked to bear down, as if to defecate, for between 10 and 20 seconds. During the coughing period, the participant was asked to cough five to seven times. Measurements for each period type were gathered twice.

We detected the rectoanal inhibitory reflex (RAIR) by injecting (with $10 \mathrm{~mL}$ increments) up to $50 \mathrm{~mL}$ of air into a rectal balloon that was attached to the head of the catheter probe. In the present study, we assessed if the RAIR was present or absent; RAIR was considered present if anal relaxation was $>25 \%{ }^{14}$ We recorded the threshold volume in $\mathrm{mL}$ of air required to elicit the RAIR. We also used the rectal balloon to measure rectal sensation. The rectal balloon was distended in $10 \mathrm{~mL}$ increments up to $300 \mathrm{~mL}$ of air, and the participants were instructed to describe their sensations as first sensation, desire to defecate, and urge to defecate. In the present study, we defined the defecation index as the ratio of the maximum rectal strain pressure to the minimum anal strain pressure. We used the classification system proposed by Rao et al. to define dyssynergic patterns during the period of attempted defecation, including types I to IV, in which type I was considered a rise in rectal pressure $\geq 40 \mathrm{~mm} \mathrm{Hg}$ with an increase in anal pressure, type II was considered a rise in rectal pressure $<40 \mathrm{~mm} \mathrm{Hg}$ with an increase in anal pressure, type III was considered a rise in rectal pressure $\geq 40$ $\mathrm{mm} \mathrm{Hg}$ with an absent relaxation or inadequate $(\leq 20 \%)$ relaxation of the anal sphincter, and type IV included no rise in rectal pressure and an absent relaxation or inadequate relaxation of the anal sphincter. ${ }^{15}$

Analytical results of quantitative variables were presented as means and SDs, whereas those of qualitative variables were presented as absolute values and percentages. Differences between groups were analyzed using Student ttests. We also compared anorectal manometric measurements between men and women using 3 multivariate linear regression models, including model 1 (by gender, adjusted by age), model 2 (by gender, adjusted by body mass index [BMI]), and model 3 (by gender, adjusted by both age and body mass index [BMI]). All statistical analyses were conducted using STATA 14.0 (Stata Corp, College Station, TX, USA). Statistical levels were considered significant at $p<0.05$.

\section{Results}

A total of the 76 healthy volunteers were recruited (age range: $21-73$ years old), which included 38 males (age range: 24-73 years old) and 38 females (age range: 21-68 years old). - Table 1 shows the general characteristics of the study participants. The mean age of the participants was $41.5 \pm 13.3$ years old. The proportion of study participants $\leq 40$ years old was higher among females (65.8\%) than among males (52.6\%), but this difference was not statistically significant $(p=0.24)$. The mean BMI was $22.4 \pm 2.5$ and was significantly higher among males than among females $(23.2 \pm 2.7$ versus $21.7 \pm 2.1 ; p<0.01)$. Only $14.5 \%$ of the participants were overweight (BMI $\geq 25)$, a proportion that was higher among males than among females, although the difference was not statistically significant $(p=0.19)$.

- Table 2 presents HRAM values in healthy participants. The mean functional anal canal length was $4.2 \pm 0.5 \mathrm{~cm}$, while the mean anal high-pressure zone (HPZ) length was $3.4 \pm 0.5 \mathrm{~cm}$. Within the anal pressure parameter values, the mean maximum resting pressure was the lowest, at $71.5 \pm 17.4 \mathrm{~mm} \mathrm{Hg}$, whereas the mean maximum squeeze 
Table 1 Characteristics of the 76 healthy study participants

\begin{tabular}{|c|c|c|c|c|}
\hline & Total $(n=76)$ & Male $(n=38)$ & Female $(n=38)$ & \multirow[t]{2}{*}{ p-value } \\
\hline & \multicolumn{3}{|c|}{$\mathrm{N}(\%)$ or mean (SD) } & \\
\hline Age (years old) & $41.5(13.3)$ & $40.5(13.4)$ & $42.6(13.2)$ & 0.49 \\
\hline \multicolumn{5}{|c|}{ Age group (years old) } \\
\hline$\leq 40$ & $45(59.2)$ & $20(52.6)$ & $25(65.8)$ & \multirow[t]{2}{*}{0.24} \\
\hline$\leq 40$ & $31(40.8)$ & $18(47.4)$ & $13(34.2)$ & \\
\hline $\mathrm{BMI}$ & $22.4(2.5)$ & $23.2(2.7)$ & $21.7(2.1)$ & $<0.01$ \\
\hline \multicolumn{5}{|l|}{ BMI } \\
\hline$<25$ & $65(85.5)$ & $30(79.8)$ & $35(92.1)$ & \multirow[t]{2}{*}{0.19} \\
\hline$\geq 25$ & $11(14.5)$ & $8(21.2)$ & $3(7.9)$ & \\
\hline
\end{tabular}

Abbreviations: BMI, body mass index; SD, standard deviation.

Table 2 High-resolution anorectal manometry parameters in 76 healthy study participants

\begin{tabular}{|c|c|c|}
\hline & $\mathrm{N}(\%)$ or mean (SD) & Min-Max \\
\hline Functional anal canal length $(\mathrm{cm})$ & $4.2(0.5)$ & $3.2-4.8$ \\
\hline HPZ length (cm) & $3.4(0.5)$ & $2.4-4$ \\
\hline \multicolumn{3}{|l|}{ Anal pressure } \\
\hline Maximum resting pressure $(\mathrm{mm} \mathrm{Hg})$ & $71.5(17.4)$ & $31.3-115.9$ \\
\hline Maximum squeeze pressure $(\mathrm{mm} \mathrm{Hg})$ & $163.3(59.1)$ & $52.2-355.5$ \\
\hline Maximum cough pressure $(\mathrm{mm} \mathrm{Hg})$ & $99.5(31.2)$ & $38.4-191.5$ \\
\hline Maximum strain pressure $(\mathrm{mm} \mathrm{Hg})$ & $74.7(28.9)$ & $23.4-169.1$ \\
\hline \multicolumn{3}{|l|}{ Rectal pressure } \\
\hline Maximum cough pressure $(\mathrm{mm} \mathrm{Hg})$ & $89.8(35.1)$ & $36.1-197.3$ \\
\hline Maximum strain pressure $(\mathrm{mm} \mathrm{Hg})$ & $63.1(26.3)$ & $18.8-163.1$ \\
\hline Defecation index & $1.4(0.8)$ & $0.3-5$ \\
\hline Threshold volume to elicit RAIR (ml) & $18.1(8.3)$ & $10-50$ \\
\hline \multicolumn{3}{|l|}{ Rectal sensation } \\
\hline First sensation $(\mathrm{mL})$ & $32.4(10.9)$ & $20-60$ \\
\hline Desire to defecate $(\mathrm{mL})$ & $81.6(19.3)$ & $50-120$ \\
\hline Urge to defecate $(\mathrm{mL})$ & $159.9(31.5)$ & $100-240$ \\
\hline \multicolumn{3}{|l|}{ Dyssynergic pattern } \\
\hline Normal & $38(50.0)$ & NA \\
\hline Type I & $21(27.6)$ & NA \\
\hline Type II & $3(3.9)$ & NA \\
\hline Type III & $11(14.6)$ & NA \\
\hline Type IV & $3(3.9)$ & NA \\
\hline
\end{tabular}

Abbreviations: HPZ, high-pressure zone; NA, not applicable; RAIR, rectoanal inhibitory reflex; SD, standard deviation.

pressure was the highest, at $163.3 \pm 59.1 \mathrm{~mm} \mathrm{Hg}$. For the rectal pressure parameter values, the mean maximum cough pressure was higher than the mean maximum strain pressure. The mean defecation index was $1.4 \pm 0.8$, with values ranging from 0.3 to 5.0. The mean threshold volume to elicit the RAIR was $18.1 \mathrm{~mL}$. Mean rectal sensation values were $32.4 \mathrm{~mL}, 81.6 \mathrm{~mL}$, and $159.0 \mathrm{~mL}$ at the first sensation, the desire to defecate, and the urge to defecate, respectively.
Dyssynergic patterns occurred in $~ 50 \%$ of the participants and included mainly types I (27.6\%) and III (14.6\%).

High-resolution anorectal manometry values are presented in - Table 3 according to the gender of the participants, age group, and BMI group. There were significant differences between males and females in the means of maximum anal squeeze pressure, maximum anal cough pressure, maximum anal strain pressure, maximum rectal 
74 Normal Values and Associated Factors in High-resolution Anorectal Manometry Anh et al.

Table 3 High-resolution anorectal manometry parameters in 76 healthy participants according to gender, age group, and BMI group

\begin{tabular}{|c|c|c|c|c|c|c|c|c|c|}
\hline & \multicolumn{3}{|l|}{ Gender } & \multicolumn{3}{|c|}{ Age group (years old) } & \multicolumn{3}{|l|}{ BMI group } \\
\hline & $\begin{array}{l}\text { Male } \\
(n=38)\end{array}$ & $\begin{array}{l}\text { Female } \\
(n=38)\end{array}$ & \multirow[t]{2}{*}{ p-value } & $\begin{array}{l}\leq 40 \\
(n=45)\end{array}$ & $\begin{array}{l}>40 \\
(n=31)\end{array}$ & \multirow[t]{2}{*}{ p-value } & $\begin{array}{l}\mathrm{BMI}<25 \\
(n=65)\end{array}$ & $\begin{array}{l}\mathrm{BMI} \geq 25 \\
(n=11)\end{array}$ & \multirow[t]{2}{*}{$p$-value } \\
\hline & \multicolumn{2}{|c|}{$\mathrm{N}(\%)$ or mean (SD) } & & \multicolumn{2}{|c|}{$\mathrm{N}(\%)$ or mean (SD) } & & \multicolumn{2}{|c|}{$\mathrm{N}(\%)$ or mean (SD) } & \\
\hline $\begin{array}{l}\text { Functional anal ca- } \\
\text { nal length }(\mathrm{cm})\end{array}$ & $4.3(0.5)$ & $4.1(0.5)$ & 0.09 & $4.2(0.5)$ & $4.3(0.5)$ & 0.40 & $4.1(0.5)$ & $4.7(0.3)$ & $<0.01$ \\
\hline HPZ length $(\mathrm{cm})$ & $3.5(0.5)$ & $3.3(0.5)$ & 0.09 & $3.4(0.5)$ & $3.5(0.5)$ & 0.40 & $3.3(0.5)$ & $3.9(0.3)$ & $<0.01$ \\
\hline \multicolumn{10}{|l|}{ Anal pressure } \\
\hline $\begin{array}{l}\text { Maximum resting } \\
\text { pressure }(\mathrm{mm} \mathrm{Hg})\end{array}$ & $74.9(16.3)$ & $68.0(18.0)$ & 0.08 & 73.7 (17.9) & $68.2(16.4)$ & 0.18 & $70.3(18.4)$ & $78.1(7.8)$ & 0.17 \\
\hline $\begin{array}{l}\text { Maximum } \\
\text { squeeze pressure } \\
(\mathrm{mm} \mathrm{Hg})\end{array}$ & $183.3(48.0)$ & $143.3(62.0)$ & $<0.01$ & $159.3(60.1)$ & $169.0(58.1)$ & 0.48 & $161.2(58.5)$ & $175.4(64.6)$ & 0.47 \\
\hline $\begin{array}{l}\text { Maximum cough } \\
\text { pressure }(\mathrm{mm} \mathrm{Hg})\end{array}$ & $112.2(31.9)$ & $86.7(24.8)$ & $<0.01$ & $99.7(29.4)$ & $99.2(34.0)$ & 0.94 & $97.5(30.1)$ & $111.0(36.2)$ & 0.19 \\
\hline $\begin{array}{r}\text { Maximum strain } \\
\text { pressure }(\mathrm{mm} \mathrm{Hg})\end{array}$ & $84.1(28.4)$ & $65.4(26.7)$ & $<0.01$ & $73.9(28.9)$ & $76.0(29.4)$ & 0.76 & $71.3(28.9)$ & $95.2(20.3)$ & 0.01 \\
\hline \multicolumn{10}{|l|}{ Rectal pressure } \\
\hline $\begin{array}{l}\text { Maximum cough } \\
\text { pressure }(\mathrm{mm} \mathrm{Hg})\end{array}$ & $101.7(38.7)$ & $78.0(26.7)$ & $<0.01$ & $81.4(34.2)$ & $102.1(33.2)$ & 0.01 & $87.5(34.2)$ & $103.5(39.3)$ & 0.17 \\
\hline $\begin{array}{r}\text { Maximum strain } \\
\text { pressure }(\mathrm{mm} \mathrm{Hg})\end{array}$ & $75.1(27.6)$ & $51.0(18.5)$ & $<0.01$ & $58.1(24.4)$ & $70.3(27.7)$ & 0.04 & $61.3(25.3)$ & $73.8(31.1)$ & 0.15 \\
\hline Defecation index & $1.4(0.7)$ & $1.4(0.8)$ & 0.93 & $1.4(0.8)$ & $1.4(0.7)$ & 0.92 & $1.4(0.8)$ & $1.1(0.5)$ & 0.28 \\
\hline $\begin{array}{l}\text { Threshold volume } \\
\text { to elicit RAIR (mL) }\end{array}$ & $18.7(9.1)$ & $17.5(7.5)$ & 0.53 & $16.3(8.6)$ & $20.6(7.3)$ & 0.02 & $18.1(8.5)$ & $18.2(7.5)$ & 0.97 \\
\hline \multicolumn{10}{|l|}{ Rectal sensation } \\
\hline $\begin{array}{l}\text { First sensation } \\
(\mathrm{mL})\end{array}$ & $32.6(10.6)$ & $32.1(11.4)$ & 0.83 & $28.4(7.1)$ & $38.1(13.0)$ & $<0.01$ & $31.2(10.4)$ & $39.1(12.2)$ & 0.03 \\
\hline $\begin{array}{l}\text { Desire to defe- } \\
\text { cate }(\mathrm{mL})\end{array}$ & $79.2(18.4)$ & $83.9(20.2)$ & 0.29 & 76.7 (17.6) & $88.7(19.8)$ & $<0.01$ & $80.6(18.9)$ & $87.3(21.5)$ & 0.29 \\
\hline $\begin{array}{l}\text { Urge to defecate } \\
(\mathrm{mL})\end{array}$ & $159.2(30.6)$ & $160.5(32.7)$ & 0.86 & $156.9(32.6)$ & $164.2(29.8)$ & 0.32 & $159.2(30.6)$ & $163.6(35.6)$ & 0.67 \\
\hline \multicolumn{10}{|l|}{$\begin{array}{l}\text { Dyssynergic pat- } \\
\text { tern- } \mathrm{N}(\%)\end{array}$} \\
\hline Normal & $16(42.1)$ & 22 (57.9) & \multirow[t]{5}{*}{0.10} & 22 (48.9) & $16(51.6)$ & \multirow[t]{5}{*}{1.00} & 34 (52.3) & $4(36.4)$ & \multirow[t]{5}{*}{0.43} \\
\hline Type I & $14(36.8)$ & $7(18.4)$ & & $12(26.7)$ & $9(29.0)$ & & 16 (24.6) & $5(45.4)$ & \\
\hline Type II & $0(0.0)$ & $3(7.9)$ & & $2(4.4)$ & $1(3.2)$ & & $2(3.1)$ & $1(9.1)$ & \\
\hline Type III & 7 (18.5) & $4(10.5)$ & & 7 (15.6) & $4(12.9)$ & & $10(15.4)$ & $1(9.1)$ & \\
\hline Type IV & $1(2.6)$ & $2(5.3)$ & & $2(4.4)$ & $1(3.3)$ & & $3(4.6)$ & $0(0.0)$ & \\
\hline
\end{tabular}

Abbreviations: BMI, body mass index; HPZ, high-pressure zone; RAIR, rectoanal inhibitory reflex; SD, standard deviation.

cough pressure, and maximum rectal strain pressure (all $p<0.01$ ). Regarding age, mean maximum rectal cough pressure and maximum rectal strain pressure were significantly higher in people aged $>40$ years old than in those aged $\leq$ 40 years old (both $p<0.05$ ). The threshold volume to elicit the RAIR among people $>40$ years was higher than that among people $\leq 40$ years old ( $p=0.02$ ). The volume at the first sensation and at the desire to defecate was higher among people $>40$ years old when compared with those $\leq$ 40 years old (both $p<0.01$ ). The length of both the functional anal canal and the HPZ was significantly greater in people with a $\mathrm{BMI}>25$ than in people with a $\mathrm{BMI}<25$ (both $p<0.01$ ). Anal pressure values tended to be higher in people with a $\mathrm{BMI}>25$ than in people with $\mathrm{BMI}<25$, but the difference was significant only with the maximum anal strain pressure $(p=0.01)$. Furthermore, difference in rectal sensation between people with a BMI $>25$ and those with a $\mathrm{BMI}<25$ were significant at the rectal first sensation $(p=0.01)$, but not at the other two rectal sensation parameters. Finally, linear regressions were performed to assess the effect of gender (adjusted for age, BMI, or both age and BMI) on the various HRAM parameters (-Table 4). Significant differences in mean maximum anal squeeze pressure, maximum anal cough pressure, maximum anal strain pressure, 
Table 4 Multiple linear regression analyses of various high-resolution anorectal manometry parameters for gender (ref.: female) according to various models

\begin{tabular}{|c|c|c|c|c|c|c|}
\hline & \multicolumn{2}{|l|}{ Model 1} & \multicolumn{2}{|l|}{ Model 2} & \multicolumn{2}{|l|}{ Model 3} \\
\hline & $\beta(95 \% \mathrm{Cl})$ & p-value & $\beta(95 \% \mathrm{Cl})$ & p-value & $\beta(95 \% \mathrm{Cl})$ & p-value \\
\hline Functional anal canal length $(\mathrm{cm})$ & $0.20(-0.02-0.42)$ & 0.08 & $0.12(-0.11,0.34)$ & 0.31 & $0.12(-0.10-0.36)$ & 0.27 \\
\hline HPZ length $(\mathrm{cm})$ & $0.20(-0.02-0.42)$ & 0.08 & $0.12(-0.11,0.34)$ & 0.31 & $0.13(-0.10-0.36)$ & 0.27 \\
\hline \multicolumn{7}{|l|}{ Anal pressure } \\
\hline Maximum resting pressure $(\mathrm{mm} \mathrm{Hg})$ & $6.44(-1.35-14.24)$ & 0.10 & $6.58(-1.69-14.86)$ & 0.12 & $5.43(-2.84-13.70)$ & 0.19 \\
\hline Maximum squeeze pressure $(\mathrm{mm} \mathrm{Hg})$ & $40.56(14.75-66,37)$ & $<0.01$ & $40.32(13.31-67.32)$ & $<0.01$ & $41.47(13.98-68.96)$ & $<0.01$ \\
\hline Maximum cough pressure $(\mathrm{mm} \mathrm{Hg})$ & $24.82(11.75-37.89)$ & $<0.01$ & $24.94(11.15-38.72)$ & $<0.01$ & $23.48(9.59-37.38)$ & $<0.01$ \\
\hline Maximum strain pressure $(\mathrm{mm} \mathrm{Hg})$ & $18.66(5.95-31.37)$ & $<0.01$ & $15.81(2.72-28.89)$ & 0.02 & $15.15(1.84-28.45)$ & 0.03 \\
\hline \multicolumn{7}{|l|}{ Rectal pressure } \\
\hline Maximum cough pressure $(\mathrm{mm} \mathrm{Hg})$ & $24.81(9.79-39.84)$ & $<0.01$ & $15.75(0.96-30.54)$ & 0.04 & $16.95(1.97-31.93)$ & 0.03 \\
\hline Maximum strain pressure $(\mathrm{mm} \mathrm{Hg})$ & $24.68(13.93-35.43)$ & $<0.01$ & $20.70(9.67-31.73)$ & $<0.01$ & $21.39(10.19-32.60)$ & $<0.01$ \\
\hline Defecation index & $-0.01(-0.36-0.34)$ & 0.96 & $-0.04(-0.40-0.33)$ & 0.84 & $-0.03(-0.40-0.35)$ & 0.89 \\
\hline Threshold volume needed to elicit RAIR (mL) & $1.39(-2.40-5.19)$ & 0.47 & $0.94(-3.07-4.94)$ & 0.64 & $1.36(-2.68-5.40)$ & 0.51 \\
\hline \multicolumn{7}{|l|}{ Rectal sensation } \\
\hline First sensation $(\mathrm{mL})$ & $1.38(-3.05-5.81)$ & 0.54 & $-1.16(-6.30-3.99)$ & 0.66 & $0.45(-4.22-5.12)$ & 0.85 \\
\hline Desire to defecate $(\mathrm{mL})$ & $-3.55(-11.77-4.67)$ & 0.39 & $-6.51(-15.72-2.70)$ & 0.16 & $-4.20(-12.94-4.55)$ & 0.34 \\
\hline Urge to defecate $(\mathrm{mL})$ & $-0.63(-15.13-13.86)$ & 0.93 & $-3.06(-18.28-12.16)$ & 0.69 & $-1.84(-17.26-13.58)$ & 0.81 \\
\hline
\end{tabular}

Abbreviations: $\beta$, coefficient; BMI, body mass index; $\mathrm{Cl}$, confidence interval; HPZ, high-pressure zone; Model 1, gender adjusted by age; Model 2, gender adjusted by BMI; Model 3, gender adjusted by age and BMI; SD, standard deviation.

maximum rectal cough pressure, and maximum rectal strain pressure between male and female participants were recorded (all $p<0.05$ ).

\section{Discussion}

The present study is the first to report normal HRAM values in healthy Vietnamese adults, and it includes predominately anorectal pressure and rectal sensation values. In addition, we also measured other values, including functional anal canal length, HPZ length, defecation index, and the threshold volume to elicit the RAIR. All HRAM values were compared by gender, age group, and BMI, in which anorectal pressure and rectal sensation values were significantly different between men and women. We found that a significant proportion of healthy people had dyssynergic patterns during simulated defecation while in a prone position. The present study provided evidence of normal HRAM values, along with the proportion of dyssynergic patterns in healthy adults, which may be considered baseline data with which to compare clinical measurements to enhance diagnosis and treatment for anorectal diseases in Vietnam, and to allow comparison with future studies.

Our results also show similarities in the patterns and range of values when compared with those of previous studies regarding normal HRAM values in healthy people. ${ }^{8-11,16}$ However, besides the values for anorectal pressure and rectal sensation, previous studies reported different parameters. Although these studies focused on normal HRAM values, they had specific goals in their reporting and methodology; therefore, the manner and structure of HRAM indicators presented differed from ours.

Except for the study conducted by Carrington et al., ${ }^{11}$ previous studies did not report functional anal canal length values. ${ }^{8-10,16}$ The mean value of functional anal canal length was slightly higher in our study than that reported by Carrington et al. ${ }^{11}$ We also did not find a significant difference in this value between males and females. We did find a significant difference in the functional anal canal length between participants with $\mathrm{BMI}<25$ and those with BMI $\geq 25$, suggesting that BMI variation could affect the functional anal canal length. In the study conducted by Paul et al., functional anal canal length was used to evaluate anal sphincter dysfunction in patients with fecal incontinence or constipation, using baseline values collected from a healthy volunteer control group. ${ }^{17}$ However, functional anal canal length did not help in the diagnosis of fecal incontinence or constipation in that study. Similarly, in the present study, HPZ values were relatively similar to those of other studies. ${ }^{9,10,18}$ We also found no difference in HPZ values according to gender and age group. Previously, it has been shown that patients with increased HPZ lengths may suffer from defecatory disorders. ${ }^{18}$ We found a statistically significant difference in HPZ values according to BMI, such that participants with a BMI $\geq 25$ had increased $\mathrm{HPZ}$ values when compared with those of participants with a $\mathrm{BMI}<25$. As such, BMI may also affect HPZ values and; therefore, we suggest that further studies be conducted to better determine how BMI and other factors influence normal HPZ values. 
The anorectal pressure values in our study are similar to those reported in previous studies, but there were certain differences. Resting pressure in our study was similar to that reported by Carrington et al., ${ }^{11}$ although our value was higher than those reported by Li et al., ${ }^{9}$ Lee et al., ${ }^{8}$ and Jones et al. ${ }^{16}$ Similar to previous reports, we found no significant difference in anal resting pressure between males and females. ${ }^{9,11}$ In a study conducted in healthy Korean people, Lee et al. reported that the maximum anal resting pressure was higher in men than in women, ${ }^{8}$ although that result may be influenced by the relatively small sample size of that study. Maximum anal squeeze pressure results from our study were lower than those of Carrington et al. ${ }^{11}$ and $\mathrm{Li}$ et al. ${ }^{9}$ However, in our study, the mean maximum anal squeeze pressure was higher than that reported by Jones et al. ${ }^{16}$ Differences in values may relate to variations among participants, measuring instruments, or measurement protocols. Furthermore, the interpersonal interaction between clinical technicians and research participants may also affect measurement results. ${ }^{19}$ As in previous studies, ${ }^{8,11}$ we also found a statistically significant difference in maximum anal squeeze pressure between men and women. In addition, we report several other values not previously mentioned, including maximum anal cough pressure, maximum anal strain pressure, maximum rectal cough pressure, and maximum rectal strain pressure. These values also tended to be higher in men than in women. We suggest that these are also important values in the evaluation of anorectal functions, and that these values can be used as a reference for the diagnosis and treatment of anorectal disorders in the future.

The defecation index is simple and easy to calculate and is very effective in assessing disorders that are related to rectoanal coordination. This index is often referred to in studies involving certain anorectal diseases. ${ }^{20,21}$ If we consider a defecation index $<1.3$ as indicative of an anorectal disorder, $\sim 50 \%$ of participants in our study displayed such a condition. However, the participants in our study were healthy people, and this is something that should be taken into account when using the defecation index in diagnosis, as its use may give false-positive results. The mean defecation index in our study is similar to that reported by Lee et al. ${ }^{8} \mathrm{We}$ also did not find significant differences in defecation index according to gender, age group, or BMI group.

Dyssynergic patterns were defined by Rao et al. to help diagnose patients with chronic constipation. ${ }^{14}$ However, most previous studies of HRAM in healthy people did not assess dyssynergic patterns. ${ }^{8-11,16}$ In one study that used Threedimensional high-definition anorectal manometry (HDAM3D), Enrique et al. reported that a dyssynergic defecation pattern occurred in $>60 \%$ of healthy study participants. ${ }^{22}$ In our study, $50 \%$ of the participants displayed a dyssynergic pattern, which is consistent with the previously reported value. We also compared the presence of a dyssynergic pattern by gender, age group, and BMI group, but we did not detect any statistically significant differences. Studies including a larger sample size should be conducted to further investigate these factors.

The RAIR is also considered an important indicator in HRAM, as it can serve as a proxy signal that associates with various anorectal disorders. ${ }^{23-26}$ In our study, the RAIR was present in all patients, but the threshold volume to elicit the RAIR was different. Although no previous studies have reported threshold volumes that elicited the RAIR using HRAM, ${ }^{23-26}$ we suggest that this is also an appropriate indicator to use as a basis for comparisons of diagnoses. We found that the threshold volume to elicit the RAIR was significantly different between the participant age groups, indicating that age might be a factor relating to changes in the structure of the anorectal area. This result is in line with a study that used HDAM-3D, ${ }^{22}$ in which Coss-Adame et al. reported that the threshold volume that elicited RAIR was $16.1 \pm 1.4 \mathrm{~mL}$ in a sample of 78 healthy participants, with no significant difference found between males and females. Using the conventional ARM method, it was suggested that RAIR may be absent in adult patients with megacolon, chronic constipation, or chronic intestinal pseudo-obstruction. $^{27-29}$ In children, however, the absence of RAIR is considered to be a highly sensitive and highly specific indicator of Hirschsprung disease. ${ }^{30}$

With regards to rectal sensation, the results of our study are similar to those reported by Li et al. ${ }^{9}$ We found no significant difference in rectal sensation between men and women. However, contrary to the findings of Li et al., we detected a significant difference in the volumes at first sensation and the threshold of desiring to defecate according to age group. ${ }^{9}$ However, in a study using HDAM-3D, CossAdame et al. reported associations between gender and values of the threshold of the desire to defecate, the urgency to defecate, and the maximal tolerable volume. ${ }^{22}$ In addition, we observed a significant difference in the volume at the first sensation according to BMI groups. We suggest that age and BMI may influence the threshold of rectal sensation, although this is in conflict with the findings of Lee et al., who also reported an association between BMI and the threshold of the first sensation, but one that was negatively correlated. ${ }^{8}$ As the mechanisms involved in rectal sensation are still unknown, possible explanations of differences between study outcomes are unclear. A study that includes a larger sample size is needed to better understand the factors related to rectal sensation.

We are aware of some limitations of the present study. The sample size was relatively small, and data were stratified according to gender, age, and BMI. The small sample size in a subgroup might thus affect statistical values during comparisons. In the present study, we mainly focused on the comparison between males and females, so it may be possible that we missed characteristics that are unique to females, such as any history of maternity-related issues. This is a single-center study, so care must be taken when applying these results to other health centers. Sampling may have been insufficient to cover all possible age groups, and it is possible that patient age may affect HRAM values. Since our study was planned and implemented prior to the standardized testing protocol and to the publication of the London classification for disorders of anorectal function, we did not apply some of the recommendations in this protocol. ${ }^{31}$ Therefore, our study results would have certain limitations 
compared with the results of other studies in the future. In addition, this is a cross-sectional study, so care must be taken when interpreting the results in a causal relationship.

\section{Conclusion}

The present study establishes normal values of HRAM in healthy Vietnamese adults, particularly regarding normal values of anorectal pressure and rectal sensation. We have found that gender is an important factor affecting anorectal pressure in healthy adults. Differences in HRAM values according to age group were only significant for rectal sensations, including the first sensation and the desire to defecate. There is almost no difference in HRAM values between BMI groups. Half of the study participants had dyssynergic patterns during the simulated strain period, among which types I and III were most prevalent. Further studies including larger sample sizes should be conducted to further confirm the constants and their relationships, and they should focus on specific age groups to identify normal values to serve as a reference for diagnosis and treatment.

\section{Ethics Approval and Consent to Participate}

All procedures performed in studies involving human participants were in accordance with the ethical standards of the Hanoi Medical University committee, Vietnam, and with the 1964 Helsinki Declaration and its later amendments or comparable ethical standards. Approval to conduct the study was obtained from the committee of the Hanoi Medical University, Vietnam, under decision no. 21NCS17/HDDDDHYHN, dated 08/02/2018. All patients gave their written, informed consent prior to inclusion in the study.

\section{Consent for Publication \\ Not applicable.}

\section{Availability of Data and Materials}

The datasets used and/or analyzed during the present study are available from the corresponding author upon reasonable request.

\section{Authors' Contributions}

Anh N. N. and Kien V. D.: study concept, study design, acquisition of data, statistical analysis, data interpretation, drafting of the manuscript. Tung L. D. and Hung N. X: study concept, critical revision of the manuscript. Cuong L. M., Hung N. X., Hang N. T. T. and Huy N. V.: data interpretation, critical revision of the manuscript. All authors have read and approved the final manuscript.

\section{Funding}

No funding or sponsorship was received for the present study or for the publication of the present article. The article processing charges were funded by the authors.

\section{Conflict of Interests}

The authors have no conflict of interests to declare.

\section{Acknowledgments}

The authors thank the healthy volunteers who participated in the present study.

\section{References}

1 Azpiroz F, Enck P, Whitehead WE. Anorectal functional testing: review of collective experience. Am J Gastroenterol 2002;97(02): $232-240$

2 Lee TH, Bharucha AE. How to Perform and Interpret a Highresolution Anorectal Manometry Test. J Neurogastroenterol Motil 2016;22(01):46-59

3 Rao SS. Pathophysiology of adult fecal incontinence. Gastroenterology 2004;126(01, Suppl 1):S14-S22

4 Lunniss PJ, Gladman MA, Hetzer FH, Williams NS, Scott SM. Risk factors in acquired faecal incontinence. J R Soc Med 2004;97(03): $111-116$

5 Diamant NE, Kamm MA, Wald A, Whitehead WE. AGA technical review on anorectal testing techniques. Gastroenterology 1999; 116(03):735-760

6 Scott SM, Gladman MA. Manometric, sensorimotor, and neurophysiologic evaluation of anorectal function. Gastroenterol Clin North Am 2008;37(03):511-538, vii

7 Carrington EV, Scott SM, Bharucha A, et al; International Anorectal Physiology Working Group and the International Working Group for Disorders of Gastrointestinal Motility and Function. Expert consensus document: Advances in the evaluation of anorectal function. Nat Rev Gastroenterol Hepatol 2018;15(05): 309-323

8 Lee HJ, Jung KW, Han S, et al. Normal values for high-resolution anorectal manometry/topography in a healthy Korean population and the effects of gender and body mass index. Neurogastroenterol Motil 2014;26(04):529-537

9 Li Y, Yang X, Xu C, Zhang Y, Zhang X. Normal values and pressure morphology for three-dimensional high-resolution anorectal manometry of asymptomatic adults: a study in 110 subjects. Int J Colorectal Dis 2013;28(08):1161-1168

10 Noelting J, Ratuapli SK, Bharucha AE, Harvey DM, Ravi K, Zinsmeister AR. Normal values for high-resolution anorectal manometry in healthy women: effects of age and significance of rectoanal gradient. Am J Gastroenterol 2012;107(10):1530-1536

11 Carrington EV, Brokjaer A, Craven H, et al. Traditional measures of normal anal sphincter function using high-resolution anorectal manometry (HRAM) in 115 healthy volunteers. Neurogastroenterol Motil 2014;26(05):625-635

12 Cuong LM, Nam V, Ha TT, et al. Anorectal Functional Outcomes Following Doppler-Guided Transanal Hemorrhoidal Dearterialization: Evidence from Vietnam. Adv Ther 2020;37(03): 1136-1144

13 Lwanga SK, Lemeshow S, Organization WH. Sample size determination in health studies: a practical manual. 1991

14 Rao SS, Azpiroz F, Diamant N, Enck P, Tougas G, Wald A. Minimum standards of anorectal manometry. Neurogastroenterol Motil 2002;14(05):553-559

15 Rao SS, Patcharatrakul T. Diagnosis and Treatment of Dyssynergic Defecation. J Neurogastroenterol Motil 2016;22(03):423-435

16 Jones MP, Post J, Crowell MD. High-resolution manometry in the evaluation of anorectal disorders: a simultaneous comparison with water-perfused manometry. Am J Gastroenterol 2007;102 (04):850-855

17 Vollebregt PF, Rasijeff AMP, Pares D, et al. Functional anal canal length measurement using high-resolution anorectal manometry to investigate anal sphincter dysfunction in patients with fecal incontinence or constipation. Neurogastroenterol Motil 2019;31 (03):e13532

18 Ratuapli SK, Bharucha AE, Noelting J, Harvey DM, Zinsmeister AR. Phenotypic identification and classification of functional 
78 Normal Values and Associated Factors in High-resolution Anorectal Manometry Anh et al.

defecatory disorders using high-resolution anorectal manometry. Gastroenterology 2013;144(02):314-322.e2

19 Heinrich H, Fruehauf H, Sauter M, et al. The effect of standard compared to enhanced instruction and verbal feedback on anorectal manometry measurements. Neurogastroenterol Motil 2013;25(03):230-237, e163

20 Seong MK. Assessment of functional defecation disorders using anorectal manometry. Ann Surg Treat Res 2018;94(06): 330-336

21 Seo M, Joo S, Jung KW, et al. A high-resolution anorectal manometry parameter based on integrated pressurized volume: A study based on 204 male patients with constipation and 26 controls. Neurogastroenterol Motil 2018;30(09):e13376

22 Coss-Adame E, Rao SS, Valestin J, Ali-Azamar A, Remes-Troche JM. Accuracy and Reproducibility of High-definition Anorectal Manometry and Pressure Topography Analyses in Healthy Subjects. Clin Gastroenterol Hepatol 2015;13(06):1143$-1150 . e 1$

23 Kaur G, Gardiner A, Duthie GS. Rectoanal reflex parameters in incontinence and constipation. Dis Colon Rectum 2002;45(07): 928-933

24 Leite ACdA, Moreira MAR, Barbosa MA, Júnior HM, Leite PCCA, Moreira JPT. Clinical and manometric investigation in constipated Chagasic patients with and without megacolon. J Coloproctol (Rio J) 2019;39(02):145-152
25 Meinds RJ, Trzpis M, Broens PM. Immaturity of the rectoanal inhibitory reflex as a cause of severe constipation in newborns. Hirschsprung's Disease 2019;68:x

26 Thiruppathy K, Mason J, Akbari K, Raeburn A, Emmanuel A. Physiological study of the anorectal reflex in patients with functional anorectal and defecation disorders. J Dig Dis 2017;18 (04):222-228

27 Basilisco G, Gebbia C, Peracchi M, et al. Cerebellar degeneration and hearing loss in a patient with idiopathic myenteric ganglionitis. Eur J Gastroenterol Hepatol 2005;17(04):449-452

28 Faussone-Pellegrini MS, Fociani P, Buffa R, Basilisco G. Loss of interstitial cells and a fibromuscular layer on the luminal side of the colonic circular muscle presenting as megacolon in an adult patient. Gut 1999;45(05):775-779

29 Staller K. Role of Anorectal Manometry in Clinical Practice. Curr Treat Options Gastroenterol 2015;13(04):418-431

30 de Lorijn F, Kremer LC, Reitsma JB, Benninga MA. Diagnostic tests in Hirschsprung disease: a systematic review. J Pediatr Gastroenterol Nutr 2006;42(05):496-505

31 Carrington EV, Heinrich $\mathrm{H}$, Knowles $\mathrm{CH}$, et al; All members of the International Anorectal Physiology Working Group. The international anorectal physiology working group (IAPWG) recommendations: Standardized testing protocol and the London classification for disorders of anorectal function. Neurogastroenterol Motil 2020;32(01):e13679 